Available online at

INSECTA

Integrative Science Education and Teaching Activity Journal

Journal homepage : https://jurnal.iainponorogo.ac.id/index.php/insecta

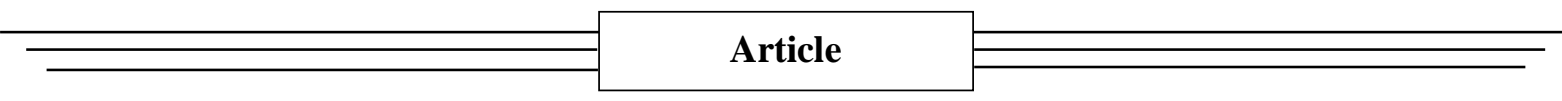

\title{
Implementation of Project Based Learning (PJBL) Based on Science, Technology, Engineering and Mathematics (STEM) to Improve Metacognitive Thinking Ability
}

\author{
Dian Fitri Mulyani ${ }^{1 *}$, Syaiful Arif ${ }^{2}$ \\ ${ }^{1,2}$ Program Studi Tadris IPA Institut Agama Islam Negeri (IAIN) Ponorogo, Ponorogo, Indonesia
}

*Corresponding Address: mulyanidianfitri@gmail.com

\section{Article Info}

Article history:

Received: March 30, 2021

Accepted: April 30, 2021

Published: May 31, 2021

\section{Keywords:}

PJBL

STEM

Metacognitive Thinking Ability

\begin{abstract}
Good learning is learning that combines an approach with an appropriate learning model. The study is done to know the implementation of a learning model with an approach to students' metacognitive thinking ability. The study is conducted with a quantitative experiment, with qualitative descriptive data analysis techniques, using the distinctive quasi design using the research of one group pretest and posttest design. Data gathering instruments are a matter of written tests with multiple choice, quetionenaire, and product design. Using a quantitative descriptive and statistic using a try t two-tailed and one-tailed that previously had done normality and homogeneity tests. Research showed that levels for extr-36,25 so it can be concluded that the experimental class has a better metacognitive thinking ability than the control class. Next up is the questionnaire results with a solution for.30.75 so that it can be concluded that the experiment class has a better ability than the control class. The next test results with incentives for 16.19 so it can be concluded that experiment classes have better abilities than control class. The impact of research that has been done is as a footing and a referencing model selection with the right approach particularly in improving metacognitive thinking ability.
\end{abstract}

\section{INTRODUCTION}

Science learning, which studies a lot about theories, will, of course, be difficult for students to understand if the teacher only explains the material and immediately gives assignments. Without being accompanied by a learning model or learning method to achieve the desired learning objectives. Learning will not be successful if it is not accompanied by an appropriate model or method. Learning that does not use the right model or method of learning will not hit students. In science learning, students will learn about concepts which of 
course have a relationship with real life. From here students will more easily understand. As we know, the successful implementation of the 2013 curriculum cannot be separated from student-centered learning. With student-centered learning activities, students will build their understanding and knowledge (Zulfa \& Rosyidah, 2020). Not only qualified in the material field but also how a teacher is able to present material attractively and can be understood by students. This will certainly be achieved by using the right learning model and choosing the right approach so that learning can be realized effectively and efficiently (Jufri \& Dwi Sulistyo Dj., 2010).

The 2013 curriculum emphasizes the activities of students. Where students are required to be more active, the implementation of the 2013 curriculum can train various skills of students, one of which is the ability to think metacognitively (Carin, A.A. \& Sund, 2016). Metacognitive thinking skills (Thinking About Thinking) emphasize more on what is suitable for students. for example, in the learning process students will understand much more about strategies suitable for their cognitive activities or in the learning process (Lestari et al., 2019; Zubaidah et al., 2018). With metacognitive thinking students are able to be independent, have more confidence in their own abilities, metacognitive thinking also trains students to be honest, and can also improve student learning outcomes and can achieve their expected educational goals.

The Project Based Learning (PJBL) learning model was chosen because this learning model can improve students' metacognitive thinking skills where the learning model is more centered on student activities (Arsal, 2017). In the approach Science, Technology, Engineering and Mathematics, it (STEM) applies various knowledge in finding knowledge so that this approach is suitable if it is in collaboration with model learning Project Based Learning (PJBL). The approach of Science, Technology, Engineering and Mathematics is also very good in developing the way students think from various aspects of knowledge in its application as well as many examples around so that they are able to build their own knowledge through their own way. The Science, Technology, Engineering and Mathematics (STEM) approach has advantages, one of which is that this approach curriculum is able to answer concerns about the right approach in science learning in accordance with research (Carin, A.A. \& Sund, 2016) ) in which Science, Technology, Engineering and Mathematics (STEM) is able to produce work-oriented individuals who are ready to work. In research (Nugent et al., 2015) ) it is necessary in the field of employment because STEM is accustomed to analyzing a problem. 21st-century education emphasizes more on quality education which can improve various skills in students. In the era of the 21 st-century, students are emphasized on mastering science and technology (Science and Technology). The 21 st-century prepares students to achieve future challenges in real-life phenomena, which place more emphasis on mastering science and developing superior human resources, creating a good and quality life.

\section{METHOD}

This research was conducted using a quantitative experimental approach, with qualitative descriptive data analysis techniques, using a type of Quasi-Experimental Design using One Group Pretest and Posttest Design research. The data collection instrument used written test questions with design multiple choise using questionnaires and products. From the results, the data obtained were analyzed using quantitative descriptive and statistical using the two-tailed test, and one-tailed which had previously been tested for normality and homogeneity. The following is the research design used in the study: 
Tabel 1. Reasearch Design

\begin{tabular}{cccc}
\hline Class & Pre Test & Treatment & Post Test \\
\hline Experiment & O1 & $\mathrm{X}$ & O2 \\
Control & O3 & - & O4
\end{tabular}

Description:

O1: Pre Test (pre-test) given before the treatment in the experimental class.

O2: Post Test (final test) given after the treatment in the experimental class.

O3: Pre Test (pre-test) given before the treatment in the control class.

O4: Post test (final test) given after treatment in the control class.

The data collection instrument is to use written test questions with design multiple choise using questionnaires and products where students are given problems around the environment then participants answer with information analysis skills and become a conclusion where the metacognitive level of students is measured with a scale of 1-4 options. all answers are made correct but can measure the level of metacognitive thinking of students. The research was conducted at SMP Negeri 1 Sawoo Ponorogo in class IXA and IXB. in class A there were 32 students and class B totaling 32 students with a total of 64 students. The technique of determining the sample uses a purposive sampling determined by the science teacher with a specific purpose.

Data collection was carried out by pre-test where students were given questions that measured metacognitive thinking skills. That step aimed to measure the initial abilities of students, then learning is carried out using the learning model Project Based Learning (PJBL) with the approach Science, Technology, Engineering and Mathematics (STEM). The Post-test was given to measure the improvement after learning took place with the model Project Based Learning (PJBL) which was carried out to measure students' metacognitive thinking skills. Data analysis using normality and homogeneity tests as prerequisite tests and t-test. After obtaining valid and reliable data results, then carried $t$ tests two-tailed and t-test one-tailed were out to determine differences in students' metacognitive thinking abilities in the experimental and control classes with tools using SPSS software.

\section{RESULTS AND DISCUSSION}

This study used technical data analysis in the form of descriptive quantitative and adjusted to the type of data and the objectives of the study. Data obtained by data collection techniques in the form of pre-test and post-test instruments using questionnaires and products to determine metacognitive thinking skills in order to answer the problem formulation in this study. The stages of data analysis in this study were as follows:

The validity test was conducted to determine the validity of the research instrument. The trial was conducted at different schools with the same class, namely SMP Negeri 1 Sawoo Ponorogo in class IX with 32 students. To test this research instrument, the test of expert judgment is to ask for an expert opinion as many as 2 experts in the field as validators. The instrument for the pre-test was 20 questions and 20 post-test questions, the questionnaire instrument consisted of 20 indicators. Then after testing the metacognitive thinking ability instrument, the data obtained were analyzed with the help of SPSS software version 16.0. The validity test used is the product-moment correlation test. Based on the validity test using the Pearson correlation on the pre-test, post-test and questionnaire instruments, it shows positive results and the results of the significant value are less than alpha, it can be decided that the pre-test, post-test and questionnaire questions are valid.

The reliability test in this study is useful to determine whether the instrument used has constant confidence in the results of the test. Measurement of the reliability test by analyzing the test results using the technique Cronbach's Alpha, the instrument is said to be reliable if it is more than 0.6 and not reliable if it is less than 0.6 . reliable test results can be seen with table 2 the help analysis using softwere SPSS 16.0 below 
Table 2. Results of Test Reliability Problem Pre-test Metacognitive Thinking Ability

\begin{tabular}{cc}
\hline \multicolumn{2}{c}{ Reliability Statistics } \\
\hline \\
Cronbach's Alpha & N of \\
.957 & Items \\
\hline
\end{tabular}

Table 3. Results of Test Reliability Problem Post-test Metacognitive Thinking Ability

\begin{tabular}{cc}
\hline \multicolumn{2}{c}{ Reliability Statistics } \\
\hline \\
Cronbach's Alpha & N of \\
.978 & Items \\
\hline
\end{tabular}

Table 4. Results of Questionnaire Reliability Test for Metacognitive Thinking Ability

\begin{tabular}{cc}
\hline \multicolumn{2}{c}{ Reliability Statistics } \\
\hline & $\mathrm{N}$ \\
of \\
Cronbach's Alpha & Items \\
.983 & 20 \\
\hline
\end{tabular}

Table 5. Product Reliability Test Results Metacognitive Thinking Ability

\begin{tabular}{lr}
\hline \multicolumn{2}{c}{ Reliability Statistics } \\
\hline Cronbach's Alpha & N of Items \\
.933 & 4 \\
\hline
\end{tabular}

Based on the resultstest cronbach's alpha instrument with 20 questions for pre-test and 20 for post-test, 20 questionnaire items, 4 indicators of product showing greater than 0.6 , it can be concluded that this instrument is reliable and can be used for data retrieval.

The normality test is a test used to determine that the data has a normal distribution. In this study, to determine that the data obtained were normally distributed, researchers used the Kolmogorov Smirnov test with the help of the SPSS sofwere. The test results can be said to be normal if the p-value is $>0.05$ and it is said to be abnormal if the p-value is $<0.05$. below is the analysis of the data obtained by the researcher.

.Table 6. Normality Test Results pretest posttest control experiment Class

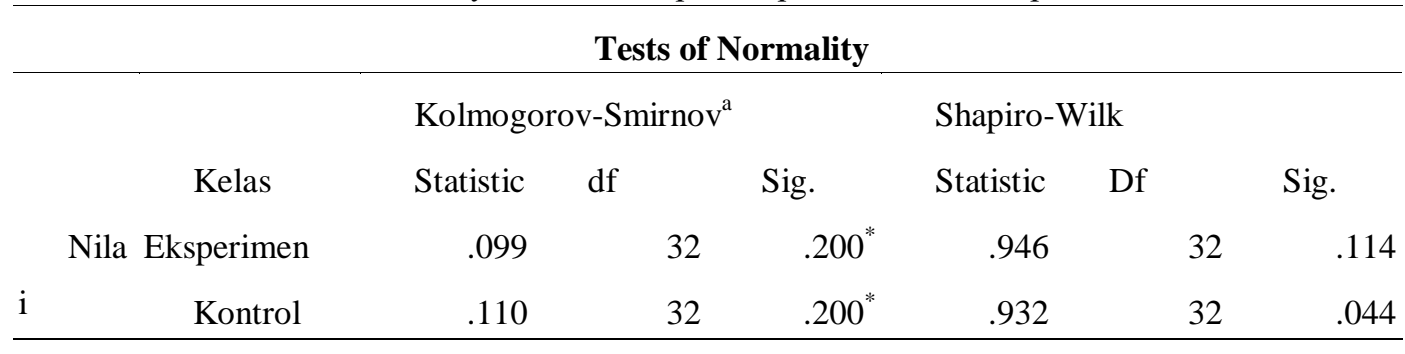


a. Lilliefors Significance Correction
*. This is a lower bound of the true significance.

Table 7. Results Normality Questionnaire Normality Test

\begin{tabular}{|c|c|c|c|c|c|c|}
\hline \multicolumn{7}{|c|}{ Tests of Normality } \\
\hline & \multicolumn{3}{|c|}{ Kolmogorov-Smirnov $^{\mathrm{a}}$} & \multicolumn{3}{|c|}{ Shapiro-Wilk } \\
\hline Kelas & Statistic & Df & Sig. & Statistic & Df & Sig. \\
\hline nilai Eksperimen & .112 & 32 & $.200^{*}$ & .942 & 32 & .086 \\
\hline Kontrol & .086 & 32 & $.200^{*}$ & .954 & 32 & .184 \\
\hline
\end{tabular}

a. Lilliefors Significance Correction

*. This is a lower bound of the true significance.

Table 8. Product Normality Test Results

\begin{tabular}{|c|c|c|c|c|c|}
\hline \multicolumn{6}{|c|}{ Tests of Normality } \\
\hline \multirow{5}{*}{ Nilai } & \multicolumn{5}{|c|}{ Kolmogorov-Smirnov $^{\mathrm{a}}$} \\
\hline & \multirow{4}{*}{$\begin{array}{l}\text { Kelas } \\
\text { Eksperiman } \\
\text { Kontrol }\end{array}$} & Statistic & Df & \multicolumn{2}{|r|}{ Sig. } \\
\hline & & \multicolumn{2}{|l|}{.105} & \multirow[t]{2}{*}{32} & \multirow[t]{2}{*}{.200} \\
\hline & & \multirow{2}{*}{\multicolumn{2}{|c|}{.231}} & & \\
\hline & & & & 17 & .016 \\
\hline
\end{tabular}

\footnotetext{
a. Lilliefors Significance Correction

*. This is a lower bound of the true significance.
}

Based on the test results above, it shows that the data obtained is normally distributed, it can be seen from the p-value above more than 0.05 , both in the pre-test and on the posttest, questionnaires and products. The significance level in the pre-test is $0,200>0.05$, the conclusion is that it is normally distributed, the post-test is also $0.200>0.05$, the questionnaire is also $0,200>0.05$, the product is also $0.200>0.05$ so that from the four the conclusion of the instrument is normally distributed.

The homogeneity test in this study aims to determine the homogeneous data collected. The data can be said to be homogeneous if the data has a $p$-value $>0.05$ and not homogeneous if the data has a $\mathrm{p}$-value $<0.05$. Below are the results of the homogeneity test using SPSS software. 
Table 9. Pretest Posttest Homogeneity Test Results for Experimental Class and Control Class

\begin{tabular}{|c|c|c|c|c|}
\hline \multicolumn{5}{|c|}{ Test of Homogeneity of Variances } \\
\hline \multicolumn{5}{|c|}{ Nilai } \\
\hline \multicolumn{5}{|c|}{ Levene } \\
\hline \multirow[t]{2}{*}{ Statistic } & & & df 2 & Sig. \\
\hline & .207 & 1 & 62 & .651 \\
\hline
\end{tabular}

Based on the test results in the table above, it can be concluded that the product data for both the control class and the experimental class are homogeneous. This can be seen from the levene's test results with a p-value of $0.444>0.05$, so it can be concluded that the data is homogeneous.

Table 10. Results of the Questionnaire Homogeneity

\begin{tabular}{cccc}
\multicolumn{4}{c}{ Test of Homogeneity of Variances } \\
\hline Nilai & & & \\
Levene & & & \\
Statistic & df1 & df2 & Sig. \\
2.091 & 1 & 62 & .153 \\
\hline
\end{tabular}

Based on the test results in the table above it can be concluded that the questionnaire data both the control and the experimental class class has been homogenized can be seen from the results levene's test with p-value results for 2091>0.05 so that it can be concluded that the data are homogeneous.

Table 11. Product Homogeneity Test Results

\begin{tabular}{rrrrrr}
\hline \multicolumn{5}{c}{ Test of Homogeneity of Variances } \\
\hline Nilai \\
Levene Statistic & df1 & & df2 & & Sig. \\
.444 & & 1 & & 47 & .508 \\
\hline
\end{tabular}

Based on the test results in the table above, it can be concluded that the product data for both the control class and the experimental class is homogeneous. This can be seen from the Levene's test results with a p-value of $0.444>0.05$, so it can be concluded that the data is homogeneous.

The t-test was used to measure the difference between the experimental class and the control class on critical thinking skills. The $t$ test was carried out with the help of thesoftware application SPSS version 16 here are the test results. 
Table 12. Results of pretest posttestexperimental class and control class

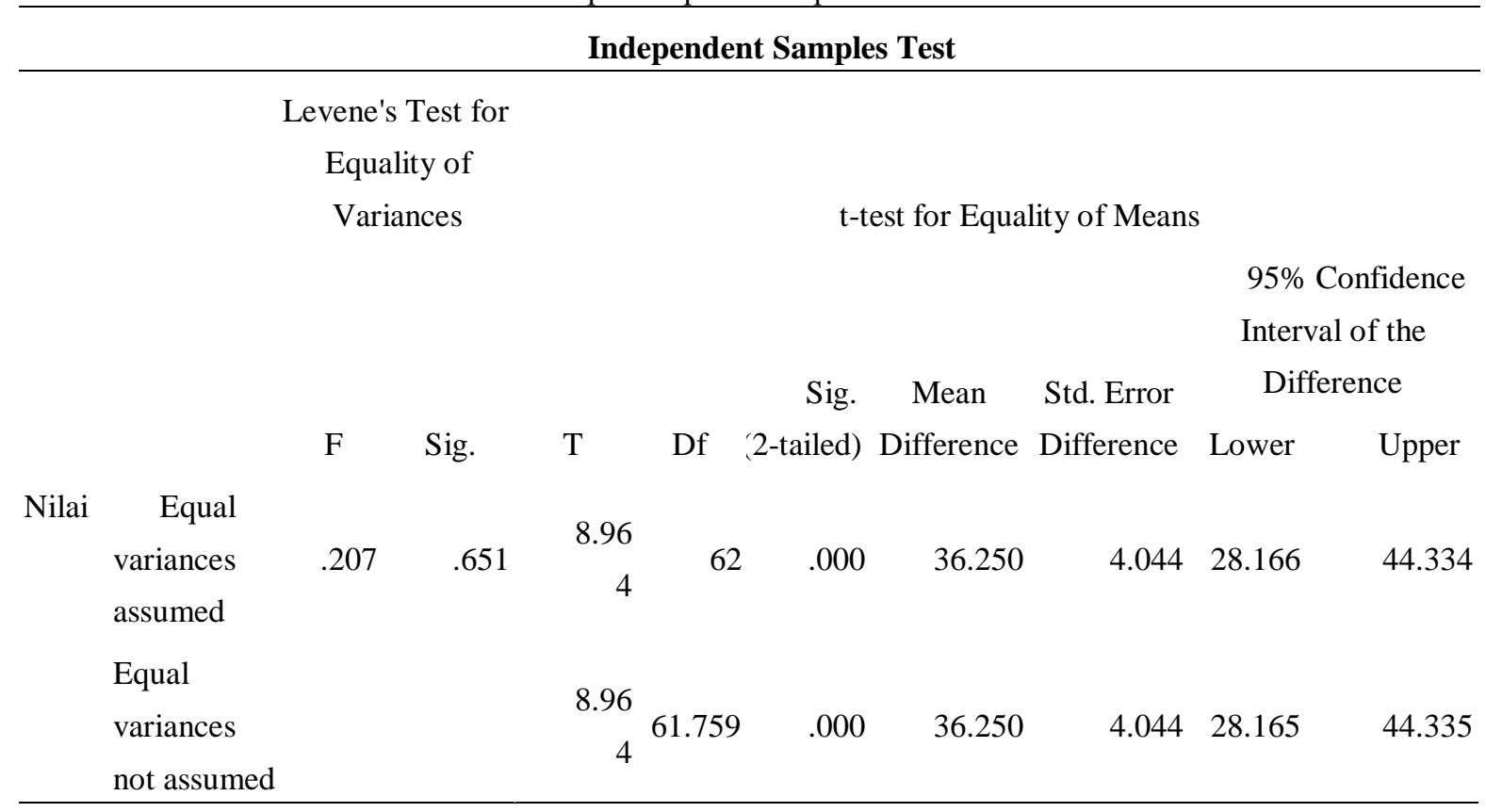

Based on t-test results of data processing showed that $p$-value of pre-test post-test is $0.000>0.05$ so it can be concluded that the experimental class and the control class have abilities that are not as good as the ability to think metacognitive.

Table 13. The t-test results of the

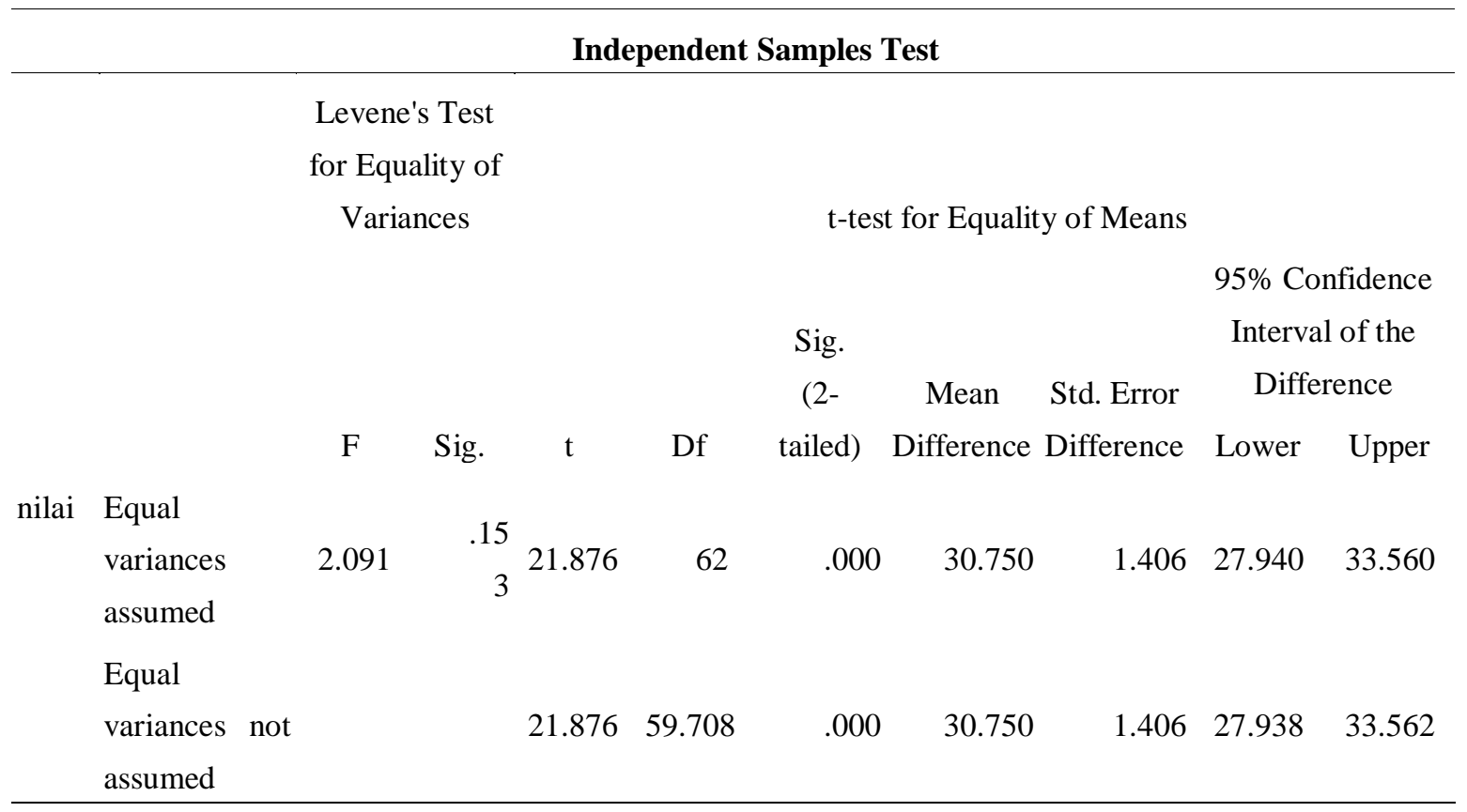

Based on t-test above the results of data processing show that the p-value of the questionnaire is $0.000>0.05$, so it can be concluded that the experimental class and the control class have abilities that are not as good as the ability to think metacognitive. The mean data in the experimental class and control class is used to see which class is superior. In the experimental class the mean data value is 88.25 , while in the control class the mean data value is 57.50 , so it can be concluded that the experimental class and the control class have different abilities. 
Table 14. The t-test results of the

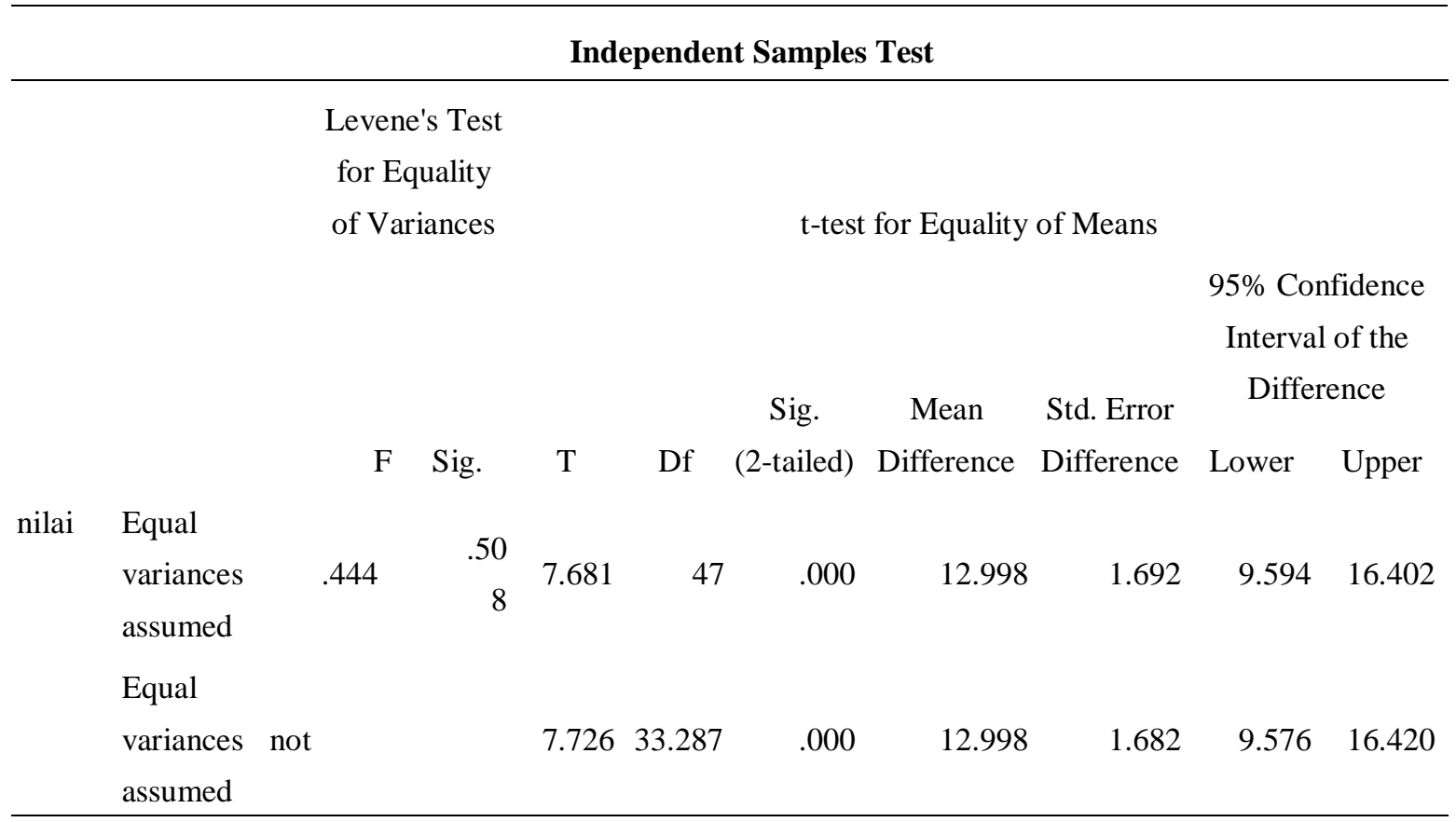

In the experimental class, the mean data value is 5.674 while in the control class the mean data value is 5.569 so it can be concluded that the experimental class has a higher metacognitive thinking ability with the learning model Project Based Learning (PJBL) with the approach Science, Technology, Engineering and Mathematics (STEM) compared to control class with conventional learning. In addition, significant differences can be seen in the test (one-tailed) as follows:

Table 15. Test Results for One-tailed Pretest Postest Experiment Class and Control Class

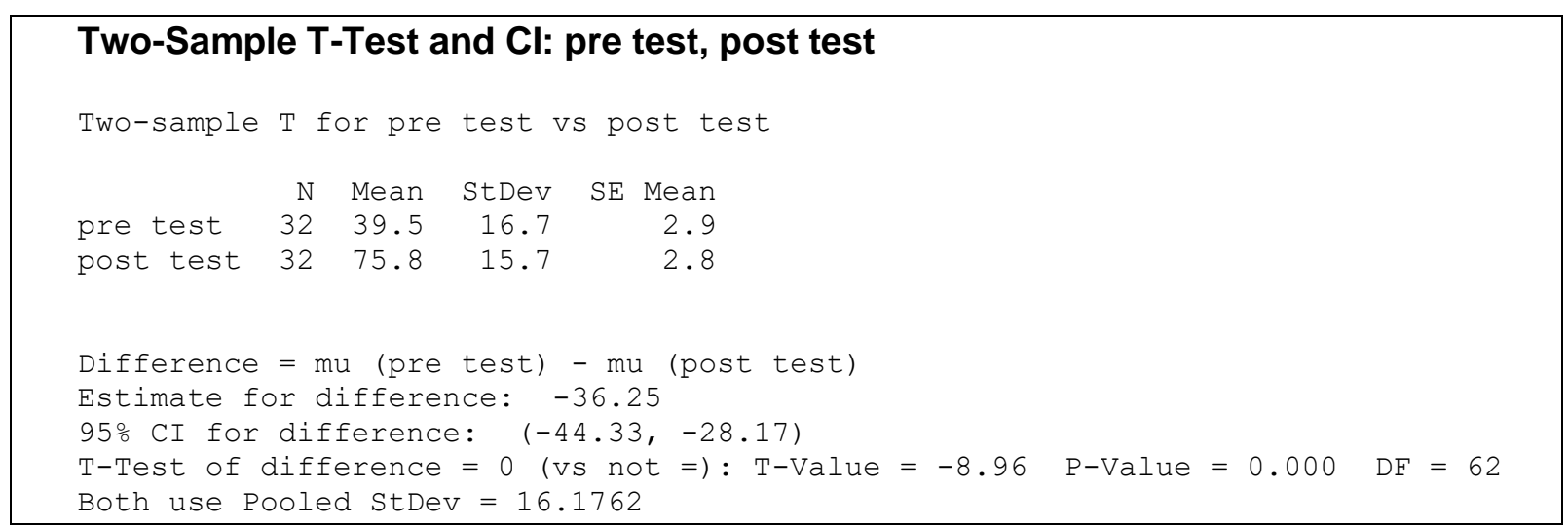

In the above test it can be seen that the p-value of 0,000 is less than 0.05 So it can be concluded that the abilities between the control class and the experimental class are not the same. To see the difference, it can be seen in Estimate for difference -36.25 so that it can be concluded that the experimental class has better abilities than the control class. 
Table 16. Test One-tailed Questionnaire for Experimental Class and Control Class

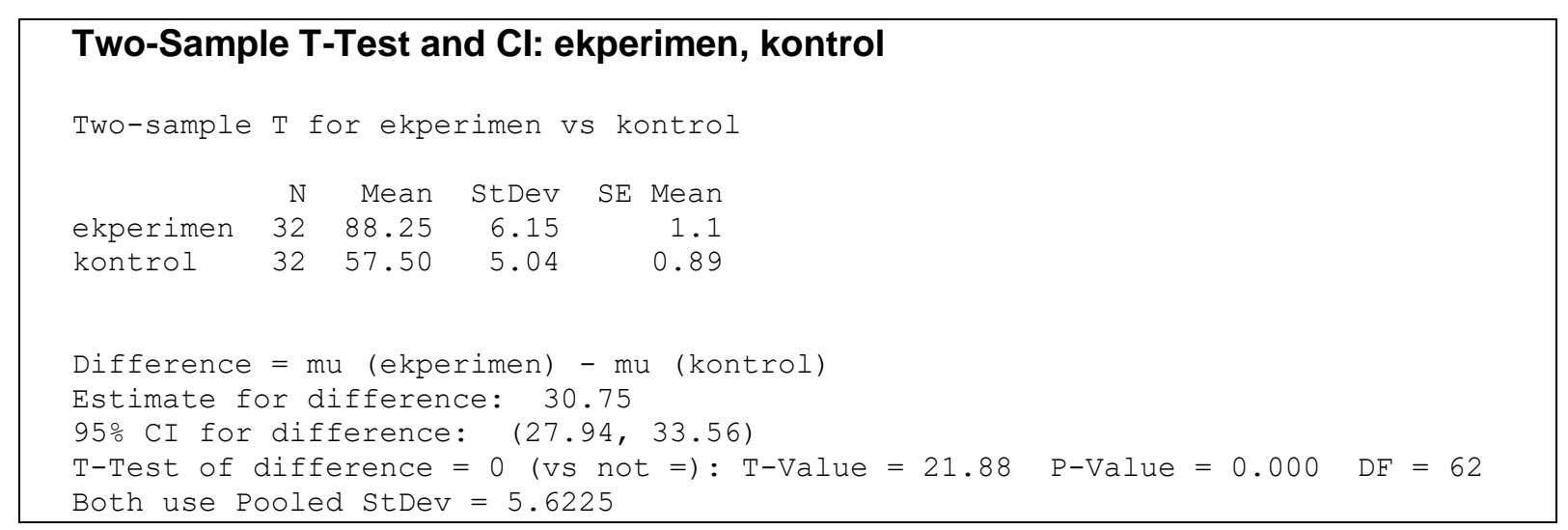

In the above test it can be seen that the p-value of 0,000 is less than 0.05 , so it can be concluded that the abilities between the control class and the experimental class are not the same. To see the difference, it can be seen in the Estimate for difference 30.75, so it can be concluded that the experimental class has better abilities than the control class.

Table 15 Test of one-tailed Products Experiment Class and Control Class

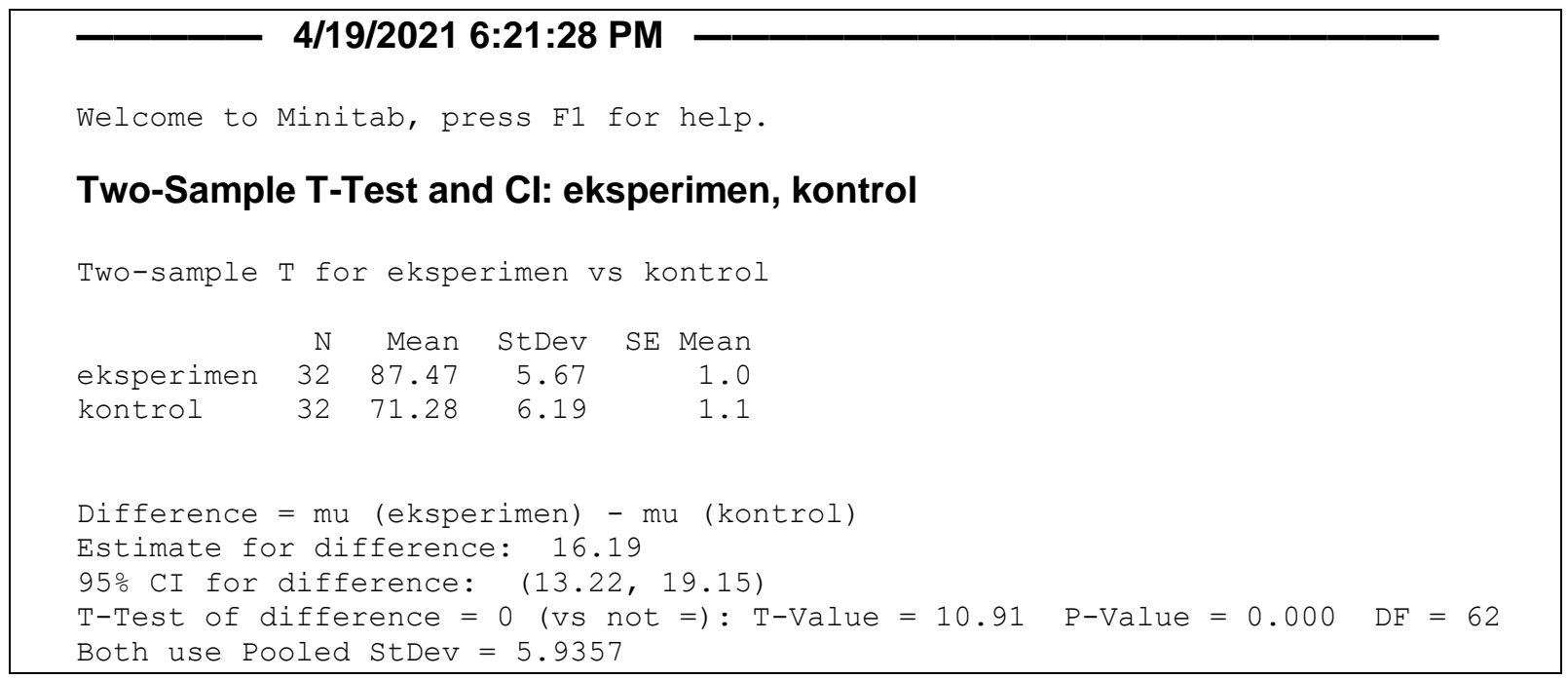

In the above test it can be seen that The p-value of 0,000 is less than 0.05 , so it can be concluded that the ability between the control class and the experimental class is not the same. To see the difference, it can be seen in Estimate for difference 16.19 so that it can be concluded that the experimental class has better abilities than the control class.

The learning implementation of the Project Based Learning (PJBL) learning model with the Science, Technology, Engineering and Mathematics (STEM) approach in Class IX science learning at SMP Negeri 1 Sawoo Ponorogo on the theme of Environmentally Friendly Technology. Learning is carried out by referring to the learning device plan prepared by the researcher. In the learning process, students are very responsive. because even though it is done online, the participants have never used video learning, usually using google classroom. In this study, researchers focused on the ability to think metacognitive by using video lessons with associated examples and applications around the students' environment. Then these abilities use the pre test to measure the initial ability and the post 
test is used to measure the ability after the experiment is carried out.

The choice of learning model is very influential in improving metacognitive thinking skills. Based on the results of research conducted by Tseng, 2013 revealed that STEMbased PJBL can increase student interest in learning, where learning is more meaningful, where the knowledge transfer process is more enjoyable and more engaging in students and helps students to solve problems in real life. and can improve various skills, one of which is metacognitive thinking skills (Suparya, 2018). Both of these variables are very useful in learning.

In improving metacognitive thinking skills, the learning model is Project Based Learning (PJBL) very good because in learning to train students starting from problem analysis, formulating problems, hypotheses, experiments, and concluding problem solving (Zubaidah, 2010). In the future it is very useful for students in selecting information that is currently widely scattered on the internet.

Based on the t-test pre-test, it can be seen that there is no significant difference between the control class and the experimental class. This can be seen from the acquisition of a p-value of 0.000 when compared to alpha, so the value is smaller. It can be concluded that Ho was rejected. The learning model Project Based Learning (PJBL) with the approach is Science, Technology, Engineering and Mathematics (STEM) able to improve students' metacognitive thinking can be seen in Estimate for difference -36.25 so that it can be concluded that the experimental class has better abilities than the control class, this is proven with between before treatment pretest and after treatment post-test. Then the students' metacognitive thinking ability can be seen in the estimate for a difference of 30.75 so that it can be concluded that the experimental class has better abilities than the control class. This is evidenced by the between before treatment pretest and after-treatment posttest. Then the students' metacognitive thinking ability can be seen in an estimate for a difference of 30.75. So it can be concluded that the experimental class has more abilities than the control class. This is evidenced by the results of the questionnaire. Then the students' metacognitive thinking ability can be seen in Estimate for difference 16.19 so that it can be concluded that the experimental class has better abilities than the control class. This is evidenced by the product results.

The Science, Technology, Engineering and Mathematics (STEM) approach is an approach that integrates the 4 components in science. In the approach Science, Technology, Engineering and Mathematics, (STEM) this can be accompanied by a learning model, namely the learning model Project Based Learning (PJBL). Where this learning model emphasizes students on contextual learning where students are given the freedom to explore their learning activities. Thisapproach Science, Technology, Engineering and Mathematics (STEM) focuses more on students on the process of solving real problems in everyday life. According to Capraro, thelearning model Project Based Learning (PJBL) which is integrated with Science, Technology, Engineering and Mathematics (STEM) provides a student experience of solving real problems carried out by practicum, so that learning can increase the effectiveness of meaningful learning (Amri et al., 2020).

The ability to think metacognitive has an important role for students in building and developing the independence of students in cognitive activities. Metacognitive thinking skills also help students to be able to control learning, plan what strategies are suitable for students to achieve the desired learning goals, monitor student learning progress, correct mistakes, evaluate mistakes from the process of evaluating students can change strategies or habits that are wrong in his cognitive processes. is the ability to be sensitive to problems in the environment, identify these problems and solve them effectively and efficiently. Therefore we need learning approaches and models that can improve metacognitive thinking skills (Suparya, 2018). In this study, the method chosen is the learning model Project Based Learning (PJBL) with the approach Science, Technology, Engineering and Mathematics (STEM). In learning research with the model, it Project Based Learning 
(PJBL) helps students to learn independently and be responsible for their own learning (Nasar \& Kurniati, 2020). Responsible for their own learning means that students find problems in the environment, then make questions about these problems, test the questions repeatedly and analyze the questions then communicate according to their findings (Pedaste et al., 2015; Strayer, 2012). The STEM approach is an approach that views a problem not only with one discipline but a combination from various angles (Jauhariyyah, Suwono, 2017). So in learning with the model Project Based Learning (PJBL) with the approach Science, Technology, Engineering and Mathematics, it (STEM) is a learning that stimulates students to ask questions related to problems they want to solve so that students are more creative and critical of a problem they want to solve.

21 st-century learning demands from being educator-centered to student-centered. This is of course to answer future challenges where students must be able to innovate in solving the problems they face. 21 st-century learning refers to the $4 \mathrm{C}$, namely skills that students must have, such as problem solving skills, critical thinking skills, cooperation skills and communication skills. One of the goals of the government in implementing the K-13 curriculum is an effort to achieve the educational goals listed in Government Regulation No. 17/2010 where the development of the potential of students who are devout to one God, have knowledge of creative and innovative critical skills, and are sensitive to the social environment. In the implementation of learning which consists of five main learning experiences, namely asking, gathering information, associating, and communicating. Learning is not only in the classroom and teachers are not the only source of learning for students.

Based on this research has important implications in learning because by implementing the learning model Project Based Learning (PJBL) with theapproach Science, Technology, Engineering and Mathematics (STEM) the learning process has implemented what is meant in the 2013 curriculum. Learning model Project Based Learning (PPA)) with theapproach Science, Technology, Engineering and Mathematics (STEM) has also been proven to be able to improve students' metacognitive thinking skills, this is in accordance with the goals of national education.

\section{CONCLUSION}

Based on research result,using the model Project Based Learning (PJBL) based on Science, Technology, Engineering and Mathematics (STEM), can be carried out well even though the implementation is done online. There is a significant difference between the control class and the experimental class, seen from the $p$-value which is 0.000 less than alpha, it can be concluded that the metacognitive thinking abilities of students are different. It can be seen in the Estimate for a difference -36.25 so that it can be concluded that the experimental class has a better ability than the control class. This is evidenced by the between before treatment pre-test and aftertreatment post-test. Then the students' metacognitive thinking ability can be seen in the estimate for a difference of 30.75 so that it can be concluded that the experimental class has better abilities than the control class. Then the students' metacognitive thinking ability can be seen in Estimate for a difference 16.19 so that the experimental class has better abilities than the control class. 


\section{REFERENCE}

Amri, M. S., Sudjimat, D. A., \& Nurhadi, D. (2020). Mengkombinasikan Project-Based Learning dengan STEM untuk Meningkatkan Hasil Belajar Teknikal dan Karakter Kerja Siswa SMK. Teknologi Dan Kejuruan: Jurnal Teknologi, Kejuruan, Dan Pengajarannya, 43(1), 41-50.

Arsal, Z. (2017). The impact of inquiry-based learning on the critical thinking dispositions of pre-service science teachers. 0693(May).

Carin, A.A. \& Sund, R. B. (2016). STEM Education: Inovasi dalam Pembelajaran Sains. Prosiding Seminar Nasional Pendidikan Sains, 2016-2023.

Jauhariyyah, Suwono, I. (2017). Science, Technology, Engineering and Mathematics Project Based Learning (STEM-PjBL) pada Pembelajaran Sains. Pros. Seminar Pend. IPA Pascasarjana UM, Vol. 2, 20

Jufri, W., \& Dwi Sulistyo Dj. (2010). Efektivitas Pembelajaran Sains Berbasis Inkuiri dengan Strategi Kooperatif dalam Meningkatkan Keterampilan Berpikir Siswa SMP. Jurnal Pendidikan Dan Pembelajaran, 17, 159-165.

Lestari, P., Ristanto, R. H., \& Miarsyah, M. (2019). Metacognitive and conceptual understanding of pteridophytes: Development and validity testing of an integrated assessment tool. Indonesian Journal of Biology Education, 2(1), 15-24.

Nasar, A., \& Kurniati, K. (2020). Comparing Students' Learning Outcomes Using Problem Based Learning Model and Inquiry Based Learning Model. Jurnal Pendidikan Fisika, $8(1), 43-55$

Nugent, G., Barker, B., Welch, G., Grandgenett, N., Wu, C. R., \& Nelson, C. (2015). A Model of Factors Contributing to STEM Learning and Career Orientation. International Journal of Science Education, 37(7), 1067-1088.

Pedaste, M., Mäeots, M., Siiman, L. A., De Jong, T., Van Riesen, S. A., Kamp, E. T., Manoli, C. C., Zacharia, Z. C., \& Tsourlidaki, E. (2015). Phases of inquiry-based learning: Definitions and the inquiry cycle. Educational Research Review, 14, 47-61.

Strayer, J. F. (2012). How learning in an inverted classroom influences cooperation, innovation and task orientation. Learning Environments Research, 15(2), 171-193.

Suparya, I. K. (2018). Pengaruh Model Pembelajaran Kooperatif Tipe Think Talk Write (Ttw) Terhadap Hasil Belajar. Widyacarya, 2.

Zubaidah, S. (2010). Berfikir Kritis: Kemampuan Berpikir Tingkat Tinggi Yang dapat Dikembangkan Melalui Pembelajaran Sains. Seminar Nasional Sains 2010 Dengan Tema “Optimalisasi Sains Untuk Memberdayakan Manusia,” January 2010, 11. 
Zubaidah, S., Corebima, A. D., \& Mahanal, S. (2018). Revealing the Relationship between Reading Interest and Critical Thinking Skills through Remap GI and Remap Jigsaw. International Journal of Instruction, 11(2), 41-56.

Zulfa, A. R., \& Rosyidah, Z. (2020). Analysis Of Communication Skills Of Junior High School Students On Classification Of Living Things Topic. Integrative Science Education and Teaching Activity Journal, 1(1), 78-92. 